\title{
TWO NEW SPECIES OF BITING MIDGES OF THE GENUS FORCIPOMYIA MEIGEN FROM ECUADOR (DIPTERA: CERATOPOGONIDAE)
}

\author{
SABRina I. Hochman ${ }^{1}$, Pablo I. Marino,", \\ and Gustavo R. SPINELLI ${ }^{3}$
}

\author{
División de Entomología, Paseo del Bosque s/n, La Plata, CP 1900, Buenos Aires, \\ Argentina; e-mails: ${ }^{1}$ sabbhoch@yahoo.com, ${ }^{2}$ pmarino@fcnym.unlp.edu.ar, \\ ${ }^{3}$ spinelli@fcnym.unlp.edu.ar \\ *Corresponding author
}

\begin{abstract}
Adults of two new species of biting midges in the subgenera Lepidohelea Kieffer and Metaforcipomyia Saunders of the genus Forcipomyia Meigen, F. (L.) ivani sp. nov. and $F$. (M.) aidae sp. nov., are described from specimens collected in Imbabura province, Ecuador at 2,320 meters above sea level. Color photographs and illustrations are provided of males and females of both new species which are compared with similar, related congeners in their respective subgenera. We also provide the first record of F. (Forcipomyia) catarinensis Marino \& Spinelli from Ecuador.
\end{abstract}

\section{$\mathscr{8}$}

Key words.- Forcipomyia (Lepidohelea), F. (Metaforcipomyia), new species, new record, Neotropical region.

\section{INTRODUCTION}

Biting midges (Diptera: Ceratopogonidae) of the genus Forcipomyia Meigen includes 1,154 extant species placed in 36 subgenera (Borkent, 2016), of which 220 species assigned to 18 subgenera inhabit the Neotropical region. This large, very diverse genus is distributed worldwide, and the adults of many species are well known important pollinators of cocoa, rubber and other tropical plants (Wirth 1991). The subgenus Lepidohelea Kieffer is presently known in the Neotropics by 22 species (Borkent \& Spinelli, 2007), but only three species have been recorded from Ecuador. The subgenus Metaforcipomyia Saunders includes 21 Neotropical species, 15 of which were recently described and/or recorded from Costa Rica (Spinelli et al. 2012), however; members of this subgenus have not been previously recorded from Ecuador.

In this article, we describe and provide photographs and illustrations of two new species in the subgenera
Lepidohelea and Metaforcipomyia from material recently collected in Ecuador. We also provide the first record of $F$. (Forcipomyia) catarinensis Marino $\&$ Spinelli from this country.

\section{MATERIALS AND METHODS}

Specimens were collected with light traps at the "Hostería Chachimbiro" in Imbabura province, Ecuador, preserved in 70\% ethanol, and subsequently slide mounted in Canada balsam by the techniques described by Borkent \& Spinelli (2007). Slide mounted specimens were examined and measured with an Olympus CH-2 compound microscope, and illustrations prepared with an attached camera lucida. Photographs were taken with a Micrometrics SE Premium digital camera attached to a Nikon Eclipse E200 compound microscope. Terms of structures follow those in the chapter on Ceratopogonidae in the Manual of Central American Diptera (Borkent et al. 2009). 
Holotypes, allotypes and paratypes of the two new species are deposited in the collection of the Museo Zoología, Pontificia Universidad Católica Ecuador, Quito, Ecuador (QCAZ); and paratypes of both species are also deposited in the collection of the División Entomología, Museo de La Plata, La Plata, Argentina (MLPA).

\section{RESUlts}

\section{Forcipomyia (Lepidohelea) ivani sp. nov.} (Figs 1-14)

Diagnosis. The only Neotropical species of the subgenus Lepidohelea with the following combination of characters: male with banded legs; gonostylus sinuate; parameres heavily sclerotized, straight, with tapered foot-shaped apices, tips divergent; and aedeagus triangular, with bluntly rounded apex. Female are very similar to females of $F$. (L.) brasiliensis Macfie and $F$. (L.) herediae Wirth \& Spinelli, but, are not presently diagnosable.

Description. Male. Head (Fig. 1) dark brown. Eyes abutting medially for a distance of the length of four ommatidia. Antenna brown, pedicel dark brown; flagellomeres 10-13 elongated, flagellomere 13 with apical nipple that is basally constricted; flagellomeres $2-9$ with long sensilla chaetica that comprise the dense plume; antennal ratio $0.71-0.78(0.76, \mathrm{n}=3)$. Palpus (Fig. 2) brown; segment 3 constricted subapically, with small, shallow, rounded mesal sensory pit; segments 4,5 completely fused, subequal in length to segment 3 ; palpal ratio $3.63-4.00(3.82, \mathrm{n}=6)$.

Thorax. Uniformly dark brown; scutellum with approximately 10 large, 6 smaller setae. Legs dark brown, hind leg slightly darker, femorotibial joints pale; tibiae with subbasal, apical pale rings; hind tibia (Fig. 3) with moderately short, nearly straight apical spur, apical comb with three medium-size spines; tarsi brown except basal $3 / 4$ of tarsomeres 1 and basal $1 / 2$ of tarsomeres 2 dark brown; tarsal ratios of fore 1.12$1.30(1.24, \mathrm{n}=6)$, mid $0.73-0.83(0.78, \mathrm{n}=6)$, and hind leg $0.74-0.92(0.84, \mathrm{n}=6)$; claws moderately stout, curved, empodia present. Wing (Fig. 4) membrane slightly infuscated, with three darkened areas, one on $2^{\text {nd }}$ radial cell, second on apex of cell $r_{3}$, and third on vein $\mathrm{CuA}_{2}$; veins $\mathrm{M}_{1}, \mathrm{M}_{2}$, and $\mathrm{CuA}_{1}$ darkened at tip; wing length $1.52-1.78(1.61, \mathrm{n}=6) \mathrm{mm}$; breadth $0.38-0.48$ $(0.45, \mathrm{n}=6) \mathrm{mm}$; costal ratio $0.39-0.44(0.42, \mathrm{n}=6)$. Halter pale brown.

Abdomen. Pale brown with darker areas on segments $2-7$, mostly on pleurae. Genitalia (Figs. 5, 12) uniformly dark brown. Tergite 9 (Fig. 12) short, posterior margin straight; sternite 9 without posteromedian excavation; tergite 10 with rounded posterior margin, cerci elongate with 3 large apical setae. Gonocoxite stout, slightly curved, $1.73 \times$ longer than broad, with short bluntly rounded mesobasal tubercle; gonostylus 0.85 length of gonocoxite, slender, slightly sinuate, with broad, bluntly rounded tip. Aedeagus (Figs. 6, 13) triangular, twice as long as basal breadth; basal arms heavily sclerotized, very short; sublateral margins slender and mesal band, heavily sclerotized; apex blunt, slightly sclerotized. Parameres (Figs. 5, 12) heavily sclerotized, slender, straight, with tapered footshaped apices, tips divergent; basal apodemes more lightly sclerotized, broad basally, curved, tapering abruptly distally, apices sharply pointed.

Female. Head (Fig. 7) dark brown. Eyes contiguous. Flagellomeres 2-8 vasiform, 9-13 slightly more elongate, slightly darker than 2-8; antennal ratio $0.83-0.86$ $(0.84, \mathrm{n}=3)$. Palpus similar to male; palpal ratio $2.75-$ $3.27(2.95, \mathrm{n}=6)$.

Thorax (Fig. 8) brown; legs dark brown, femora with pale, narrow basal band; femorotibial joints pale; tibiae with subbasal, apical pale rings, and narrow apical bands on fore, mid tibiae, broader apical band on hind tibia; tarsi brown except basal $3 / 4$ of tarsomeres 1 and basal $1 / 2$ of tarsomeres 2 dark brown; tarsal ratios of fore $1.40-1.66(1.56, \mathrm{n}=6)$, mid $0.77-1.15$ $(0.95, \mathrm{n}=6)$, and hind leg $0.96-1.10(1.00, \mathrm{n}=6)$; claws stout, curved. Wing (Fig. 9) broader than but with pattern similar to male; wing length $1.22-1.40(1.47, \mathrm{n}=6)$ $\mathrm{mm}$; breadth $0.48-0.56(0.51, \mathrm{n}=6) \mathrm{mm}$; costal ratio $0.46-0.47(0.47, \mathrm{n}=6)$.

Abdomen (Fig. 10) brown with abundant setae and flattened scales mostly on pleurae; segments 8-9 darker. Genital sclerotization (Figs. 11, 14) with nearly straight anterior margin; lumen ovoidal; basal arms moderately short, apices curved anteriorly. Sternite 10 with a single pair of long setae near apicodistal margin. Spermatheca ovoid, heavily sclerotized, with slender, straight neck, measuring 0.060 by $0.050 \mathrm{~mm}$, neck $0.004 \mathrm{~mm}$.

Distribution. Known only from the type locality, at elevations of 2,300-2,400 $\mathrm{m}$ above sea level.

Type material. Holotype male, labeled "Holotype Forcipomyia (Lepidohelea) ivani, Hochman \& Marino, Ecuador, Imbabura prov., Chachimbiro, $0^{\circ} 27^{\prime} 05.7 ” \mathrm{~N}, 78^{\circ} 13^{\prime} 44.9^{\prime \prime} \mathrm{W}, 2,320 \mathrm{~m}, 10 / 11-\mathrm{I}-2014$, S. Hochman, light trap" (QCAZ); allotype female with same data as holotype (QCAZ). Paratypes, 2 males, 2 females with same data as holotype: 1 male, 1 female (QCAZ); 1 male, 1 female (MLPA).

Other specimens examined. Same data as holotype except 22-XII-2013, 3 males, 3 females in MLPA (damaged specimens).

Etymology. This new species is named in honor of the senior author's grandfather, Ivan Roland Watson. 
Taxonomic discussion. This new species is a member of the annulatipes group as diagnosed by Wirth \& Spinelli (1993). Males of this new species key to couplet 9 in Wirth \& Spinelli (1993), however, it differs from males of $F$. (L.) herediae Wirth \& Spinelli from Costa Rica by its very slender aedeagus (aedeagus only as long as basal breadth in $F$. herediae) with a narrower apex that is shallowly bifid (apex broader, more deeply bifid in $F$. herediae). Males of $F$. (L.) bahiensis Wirth $\&$ Spinelli from Brazil and Trinidad differ from males of $F$. (L.) ivani sp. nov. by the shapes of the distal portions of their parameres that are mesally recurved with closely approximated tips, and the aedeagus is membranous and lacks heavily sclerotized sublateral margins and mesal band present in F. ivani. Males of $F$. (L.) euthystyla Wirth \& Spinelli from Colombia and Panama, also somewhat resemble those of $F$. $(L$. ivani, but the gonostylus is short, and straight, and the aedeagus is triangular and mostly membranous.

Females of $F$. bahiensis have leg patterns similar to females of $F$. ivani sp. nov., but differ in having a thicker walled genital sclerotization with a small, narrow, lumen. Females of $F$. herediae are similar to females of $F$. ivani, but differ in having a much thicker genital sclerotization with a narrower lumen, and the spermatheca has a shorter, straight neck. Females of $F$. euthystyla differ from those of $F$. ivani in having a thicker walled genital sclerotization with a shorter, 8-shaped lumen, and a shorter, broader oblique spermathecal neck.

Finally, it is worth noting that this new species is unique in the New World by only having three slender short spines at the apex of the hind tibia, but they are not in the form of a typical tibial comb that is present in other related species. Therefore, we recommend that future studies of the annulatipes species group should examine this character in Old World species.

\section{Forcipomyia (Metaforcipomyia) aidae sp. nov.} (Figs 15-30)

Diagnosis. The only Neotropical species of the subgenus Metaforcipomyia with the following combination of characters: male with a greatly elongate third palpal segment without sensory pit; labrum tapering distally, without apical setae; femora and tibiae nearly uniformly brown; wing with poorly developed pigmented pattern; flagellomere 10 greatly elongate; parameres absent; and aedeagus U-shaped with an apical Y-shaped posteriorly directed sclerite. Female wing without pigmented pattern; and spermathecae pyriform, slightly unequal in size, without necks.

Description. Male. Head (Fig. 15) brown. Eyes abutting medially for the length of three ommatidia. Antennal pedicel dark brown; flagellomeres $2-5$ spherical, 2-9 separated, flagellomere $10 \quad 2.45-2.60$ $(2.53, \mathrm{n}=2) \times$ longer than 11 , flagellomeres $10-11$ elongate; flagellomere 13 with apical nipple, constricted basally; flagellomeres $2-10$ with long sensilla chaetica that comprise the dense plume; antennal ratio 2.62-2.68 (2.65, $\mathrm{n}=2$ ). Palpus (Fig. 16) brown; segments $3-4$ elongate, slender, segment 3 without sensory pit; segment 4 (4+5 fused) subequal than 3 ; palpal ratio $4.50-4.90(4.70, \mathrm{n}=2)$. Labrum tapering distally, without apical setae.

Thorax (Fig. 17) dark brown; scutellum with 12-14 large setae and several smaller ones. Legs brown; femorotibial joints slightly paler; hind tibia with three apical spines (Fig. 18); tarsomeres 1-5 with pectinate scales, tarsomere 1 of foreleg with 6 thick reinforced setae, tarsomere 2 of foreleg with 2 similar setae; tarsomeres 1-5 without contrasting pigmentation; tarsal ratios of fore 1.58-1.66 $(1.62, \mathrm{n}=2)$, mid $1.20-1.30$ $(1.25, \mathrm{n}=2)$, and hind leg 1.19-1.24 $(1.22, \mathrm{n}=2)$; claws greatly curved, moderately stout, empodia present. Wing (Fig. 19) membrane infuscated, with pattern of pigmentation: two light spots in cell $\mathrm{r}_{3}$, one posterior to $2^{\text {nd }}$ radial cell, one subapical; faint distal light spots in cells $\mathrm{m}_{2}$, cua ${ }_{1}$ and anal cell; intercalary fork present; base of vein $\mathrm{M}_{2}$ obsolete; first radial cell obliterated, second radial cell short, well developed; fork of veins $\mathrm{CuA}_{1}$ and $\mathrm{CuA}_{2}$ considerably beyond level of apex of costa; wing length 1.54-1.56 (1.55, $\mathrm{n}=2) \mathrm{mm}$, breadth $0.46-0.48(0.47, \mathrm{n}=2) \mathrm{mm}$; costal ratio 0.39-0.40 (0.39, $\mathrm{n}=2$ ). Halter brown.

Abdomen. Tergites uniformly dark brown; sternites brown. Genitalia (Figs. 20, 28) brown, gonostyli slightly paler. Tergite 9 extending to $1 / 2$ length of gonocoxite, posterior margin rounded, cercus lobe-like, produced beyond midlength of gonocoxite with 3 large apical setae; sternite 9 broadest distally, posterior margin slightly sinuous, without posteromedian excavation. Gonocoxite straight, moderately stout, twice as long as greatest breadth; gonostylus 0.9 length of gonocoxite, almost straight, apex slightly hooked, tip pointed. Parameres absent; gonocoxal apodemes slender, nearly straight, fused anteriorly in form of narrow bridge. Aedeagus (Figs. 21, 29) U-shaped, tapering slightly distally with broad rounded tip, and an apical Y-shaped posteriorly directed sclerite; basal arch extending to $3 / 5$ of total aedeagal length; basal arms short, knob-like, heavily sclerotized.

Female. Head (Fig. 22) dark brown. Eyes contiguous for a distance equal to the width of 3-4 ommatidia. Antennal pedicel dark brown, flagellum brown; flagellomeres 1-8 vasiform, flagellomere 8 slightly shorter than $9 ; 9-13$ cylindrical, 13 longest; antennal ratio $0.75-0.76(0.76, \mathrm{n}=2)$. Palpus (Fig. 23) brown, with 4 segments, segment 3 moderately long without sensory pit; segment 4 ( $4+5$ fused), subequal to segment 3 ; palpal ratio $3.33-4.33(3.83, \mathrm{n}=2)$. 
Thorax (Fig. 24) dark brown. Legs brown, femorotibial joints lighter brown; tarsal ratios of fore 1.56-1.63 (1.60, $\mathrm{n}=2)$, mid 1.39-1.54 (1.46, $\mathrm{n}=2)$, and hind leg 1.46-1.50 (1.48, $\mathrm{n}=2)$. Wing (Fig. 25) without pigmented pattern, fork of veins $\mathrm{CuA}_{1}, \mathrm{CuA}_{2}$ situated slightly distad to level of apex of costa; wing length $1.10-1.44(1.27, \mathrm{n}=2) \mathrm{mm}$, breadth $0.46-0.60(0.53, \mathrm{n}=2) \mathrm{mm}$; costal ratio $0.36-0.42(0.39$, $\mathrm{n}=2$ ).

Abdomen (Fig. 26). Tergites brown, sternites dark brown. Genital sclerotization (Figs. 27, 30) with high arched anterior portion and short, curved internal arms that produce an arrow-head shaped lumen. Two elongate pyriform heavily sclerotized, slightly unequal spermathecae (Figs. 26, 30) without necks, measuring 0.066 by $0.038 \mathrm{~mm}, 0.062$ by $0.042 \mathrm{~mm}$ (smaller spermathecae partially collapsed in the holotype).

Distribution. Known only from the type locality, at elevations of 2,300-2,400 m above sea level.

Type material. Holotype male, labeled "Holotype Forcipomyia (Metaforcipomyia) aidae, Hochman \& Marino, Ecuador, Imbabura prov., Chachimbiro, $0^{\circ} 27^{\prime} 05.7^{\prime} \mathrm{N}, \quad 78^{\circ} 13^{\prime} 44.9^{\prime} \mathrm{W}, 2,320 \mathrm{~m}, 10 / 11-\mathrm{I}-2014$, S. Hochman, light trap" (QCAZ); allotype female, same data as holotype (QCAZ). Paratypes, 1 male, 1 female, with same data as holotype (MLPA).

Etymology. The species is named in honor of the senior author's grandmother Aida Saba Lemarie.

Taxonomic discussion. Due to the lack of parameres, the U-shaped aedeagus with an apical posteriorly directed Y-shaped sclerite and labrum that tapers apically, this new species keys to couplet 16 in Spinelli et al. (2012): F. (M.) anniae Spinelli, Marino \& Borkent and F. (M.) atenasensis Spinelli, Marino \& Borkent, both from Costa Rica. However, $F$. (M.) aidae sp. nov. differ from those two species by its nearly uniformly brown femora and tibiae, the third palpal segment lacks a sensory pit, and the wing with a pigmented pattern $\left(3^{\text {rd }}\right.$ palpal segment with sensory pit and wing plain in males of $F$. anniae and $F$. atenasensis).

Forcipomyia aidae is also very similar to $F$. (M.) longiflagellata Spinelli, Marino \& Borkent from Costa Rica, due to the greatly elongate flagellomere 10 of the male antenna, but, in the latter species parameres are present and the third palpal segment has a conspicuous pit.

The Patagonian species, $F$. (M.) moreno $i$ described by Marino \& Spinelli (2003) also resembles this new species, especially by the greatly elongate flagellomere 10 of males (flagellomere 10 ca. $2.5 \times$ longer than 11 ), but the wing lacks a pigmented pattern and the main portion of the aedeagus abruptly tapers to broad, bluntly rounded tip.

\section{NEW RECORD}

\section{Forcipomyia (Forcipomyia) catarinensis Marino and Spinelli}

Forcipomyia squamitibia Lutz: Macfie 1939: 145 (female; redescription; Brazil); Macfie 1949: 111 (male; description; fig. genitalia; Mexico).

Forcipomyia (Forcipomyia) squamitibia: Wirth 1982: 583 (male, female; description; in review of the Forcipomyia (F.) argenteola group; Brazil, Costa Rica).

Forcipomyia (Forcipomyia) catarinensis Marino and Spinelli, 2002: 309 (male, female; Brazil).

Specimens examined. Ecuador, Imbabura prov., Chachimbiro, $0^{\circ} 27^{\prime} 05.7 ” \mathrm{~N}, 78^{\circ} 13^{\prime} 44.9^{\prime} \mathrm{W}, 2,320 \mathrm{~m}$, 10/11-I-2014, S. Hochman, 1 male, 1 female, light trap (QCAZ).

Distribution. Mexico, Costa Rica, Colombia, Ecuador and Brazil (Santa Catarina).

Discussion. Forcipomyia $(F$.) catarinensis was previously regarded by Macfie $(1939,1949)$ and Wirth (1982) as Forcipomyia squamitibia, which Lutz (1914) originally described from Rio de Janeiro, Brazil. In the discussion section of their new species, $F$. $(F$.) catarinensis, Marino \& Spinelli (2002) noted that they examined the specimens from Brazil and Mexico regarded by Macfie $(1939,1949)$ as $F$. squamitibia in the Natural History Museum, London (BMNH). Marino \& Spinelli concluded that the BMNH specimen from Brazil did not resemble the lectotype of F. squamitib$i a$, which they also redescribed and illustrated. However, Marino \& Spinelli considered the Brazilian specimen described and illustrated by Macfie (1939) was conspecific with $F$. catarinensis, and designated it a paratype of that new species. We provide the first record of $F$. catarinensis from Ecuador.

\section{ACKNOWLEDGEMENTS}

We would like to thank the staff at "Hosteria Chachimbiro", for the facilities and friendship while we conducted field research on that property. We are also grateful to Dr. Clifford Keil, director of the Invertebrates collection of the Museo de Zoología QCAZ of Pontificia Universidad Católica del Ecuador, for his valuable help and guidance. Finally, we especially acknowledge the Subsecretaría and Dirección provincial of Imbabura, Ministerio del Medio Ambiente, Ecuador by the collection permission to carry out the field research.

\section{REFERENCES}

Borkent, A. 2016. World species of Biting Midges (Diptera: Ceratopogonidae). Available online from: http://www.inhs. 
illinois.edu/research/FLYTREE/CeratopogonidaeCatalog. pdf, 245 pp., last accessed May, 2016.

Borkent, A. and G. R. Spinelli. 2007. Neotropical Ceratopogonidae (Diptera: Insecta), pp. 482-553. In: Adis, J., J. R. Arias, G. Rueda Delgado and K. M. Wantzen (eds.). Aquatic Biodiversity in Latin America (ABLA). Vol. 4. Pensoft, Sofia-Moscow, 198 pp.

Borkent, A., Spinelli, G. R. and W. L. Grogan, Jr. 2009. Ceratopogonidae (biting midges, purrujas). Chapter 29. Pp. 407435. In: Brown, B. V., A. Borkent, J. M. Cumming, D. M. Wood, N. E.Woodley, \& M. A. Zumbado, (eds.). Manual of Central American Diptera. Volume 1. National Research Council Press; Ottawa, Ontario, Canada, 714 pp.

Lutz, A. 1914. Contribuição para o conhecimento das "Ceratopogoninas" do Brazil. Memorias do Instituto Oswaldo Cruz, 6: 81-99, pls. 8-9.

Macfie, J. W. S. 1939. A report on a collection of Brazilian Ceratopogonidae. Revista de Entomología, 10: 137-219.

Macfie, J. W. S. 1949. Notes on Ceratopogonidae. Proceedings of the Royal Entomological Society of London (B), 18: $109-115$.

Marino, P. I. and G. R. Spinelli. 2002. A revision of the Forcipomyia squamitibia group in the Neotropics with the description of three new species (Diptera: Ceratopogonidae). Insect Science and its Application, 22: 307-319.

Marino, P. I. and G. R. Spinelli. 2003. The Patagonian species of the subgenus Forcipomyia (Metaforcipomyia) (Diptera: Ceratopogonidae), with a key to the New World species. Insect Systematics \& Evolution, 34: 21-28.

Spinelli, G. R., Marino, P. I. and A. Borkent. 2012. A revision of Biting Midges of the Subgenera Forcipomyia (Metaforcipomyia) and F. (Saliohelea) from Costa Rica (Diptera: Ceratopogonidae). Zootaxa, 3419: 1-52.

Wirth, W. W. 1982. The cacao-pollinating midges of the Forcipomyia argenteola group (Diptera: Ceratopogonidae). Proceedings of the Entomological Society of Washington, 84: 568-585.

Wirth, W. W. 1991. New and little-known species of Forcipomyia (Diptera: Ceratopogonidae) associated with cocoa pollination in Brazil. Proceedings of the Entomological Society of Washington, 93: 163-175.

Wirth, W. W. and G. R. Spinelli. 1993. The American species of the annulatipes group of the subgenus Lepidohelea, genus Forcipomyia (Diptera: Ceratopogonidae). Insecta Mundi, 6: 109-125 (1992). 

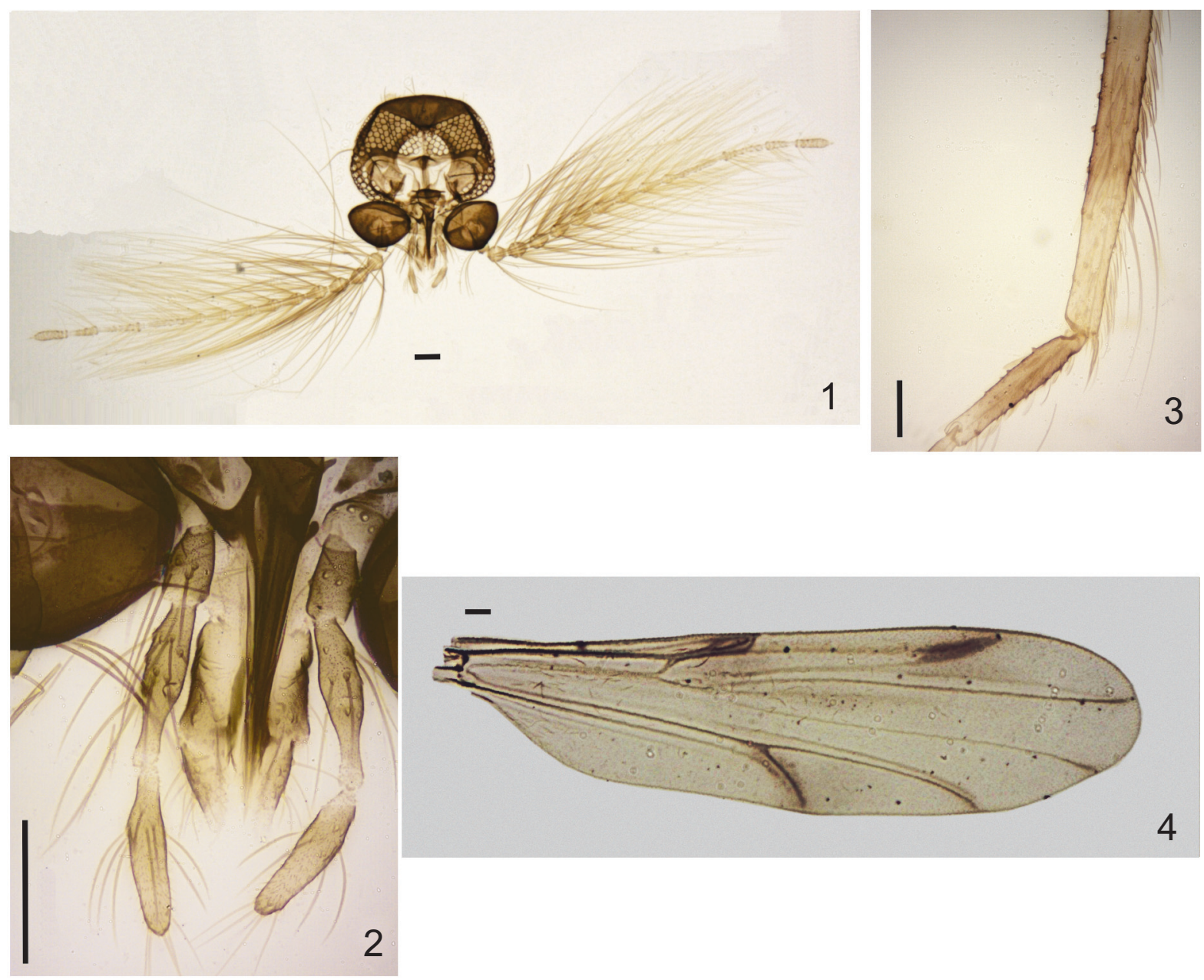

4
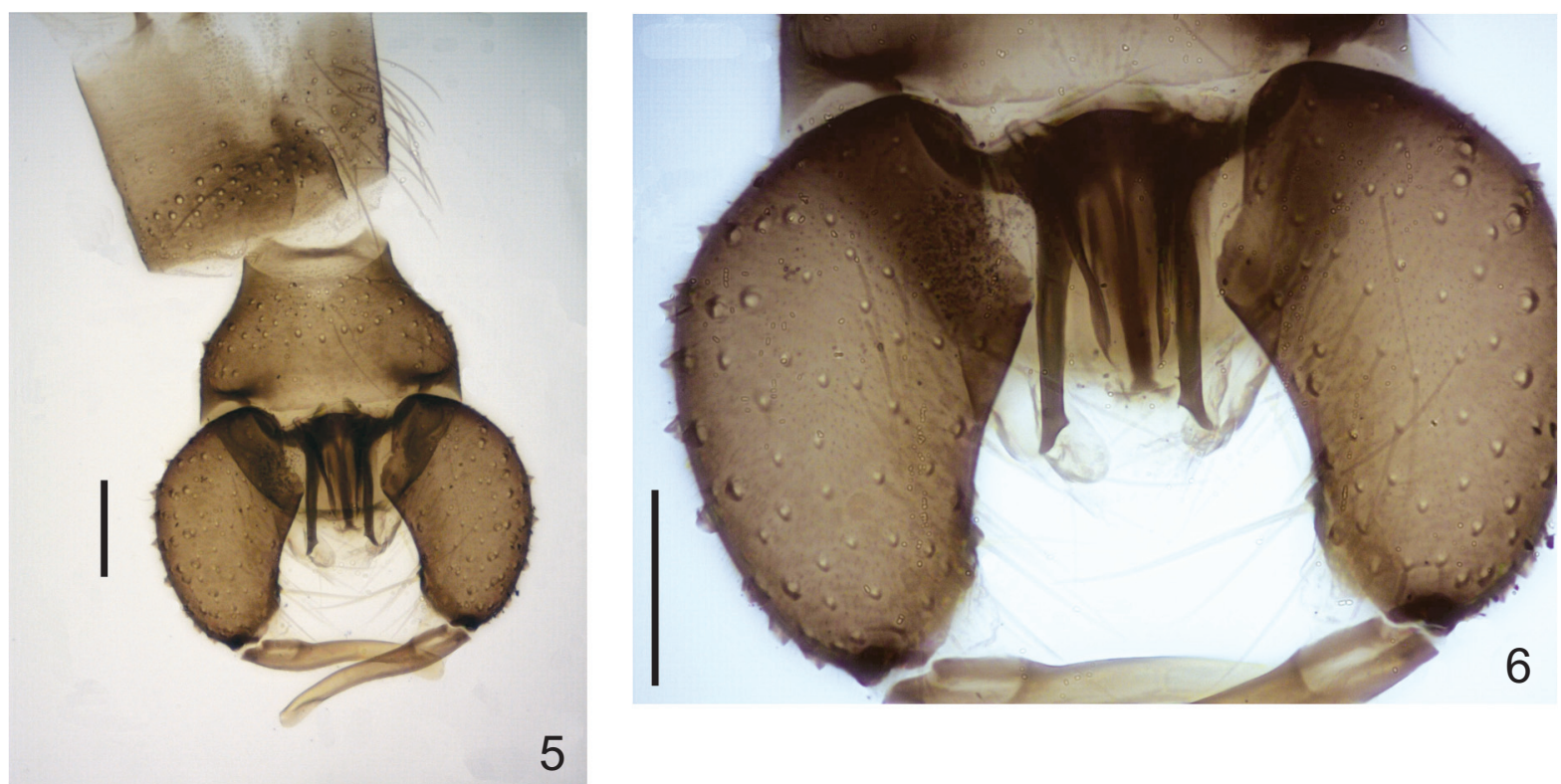

5

Figures 1-6. Forcipomyia (L.) ivani, male. (1) head; (2) palpus; (3) hind tibia; (4) wing; (5) genitalia; (6) aedeagus. 

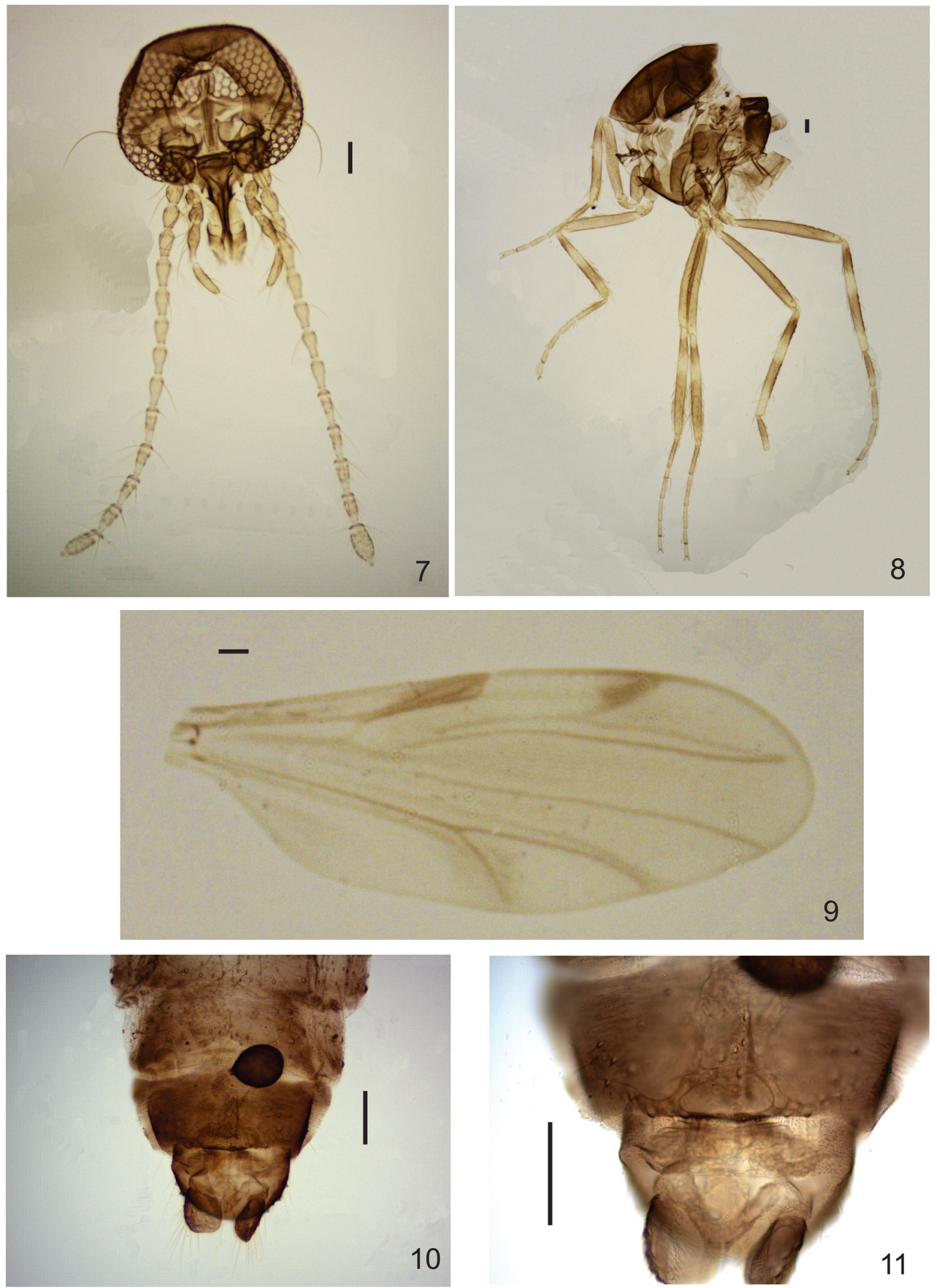

Figures 7-11. Forcipomyia (L). ivani, female. (7) head; (8) thorax; (9) wing; (10) tip of abdomen; (11) genital sclerotization. 

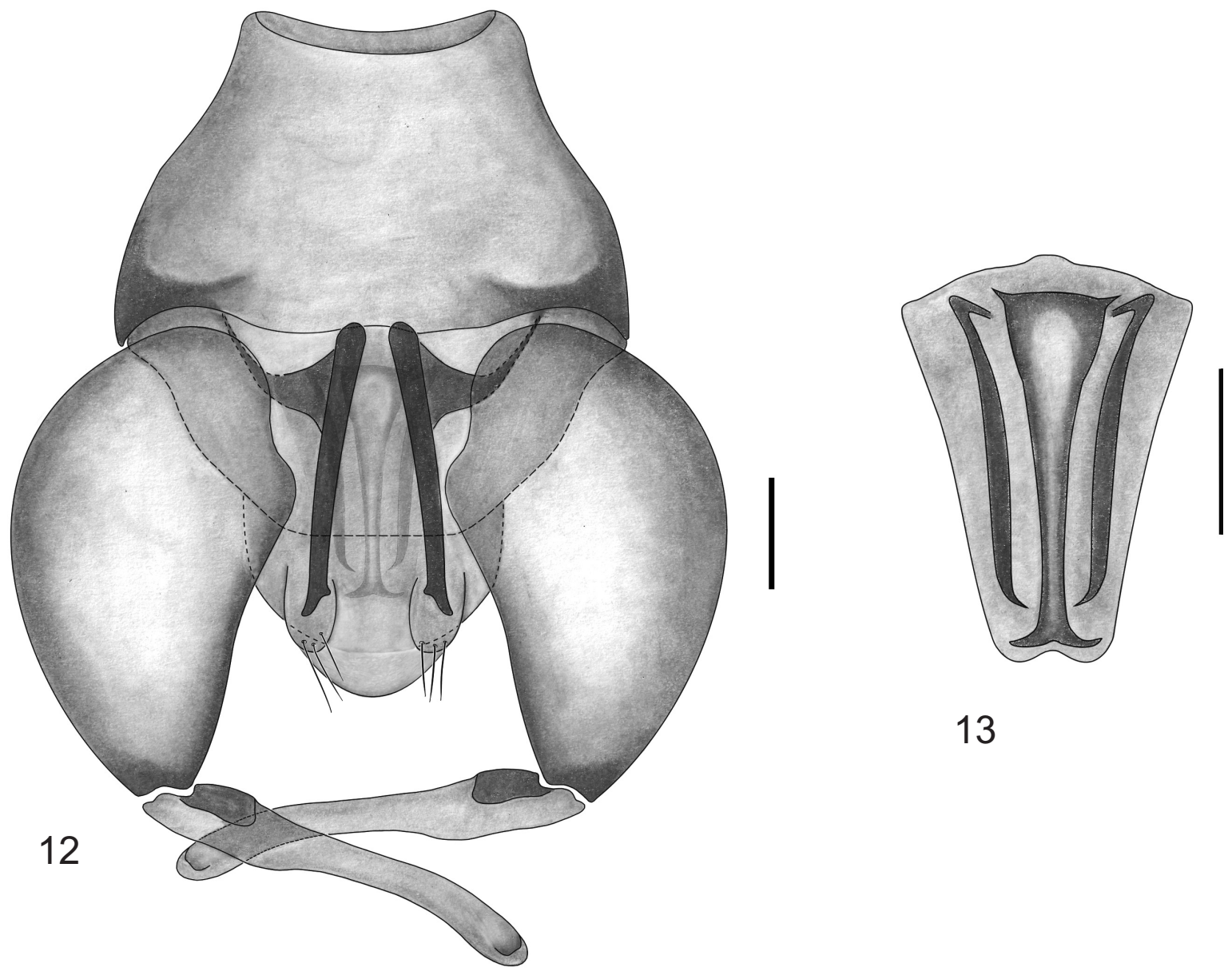

13

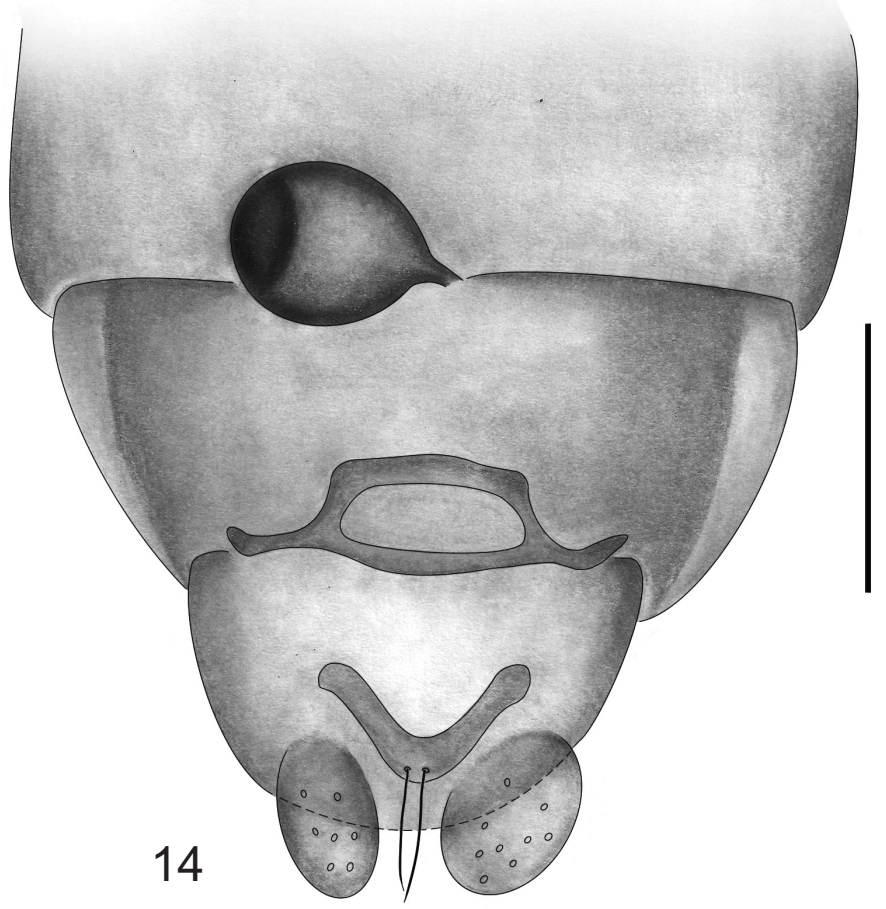

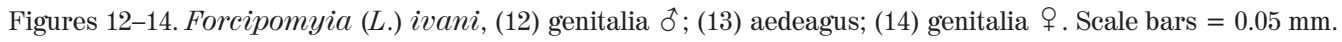



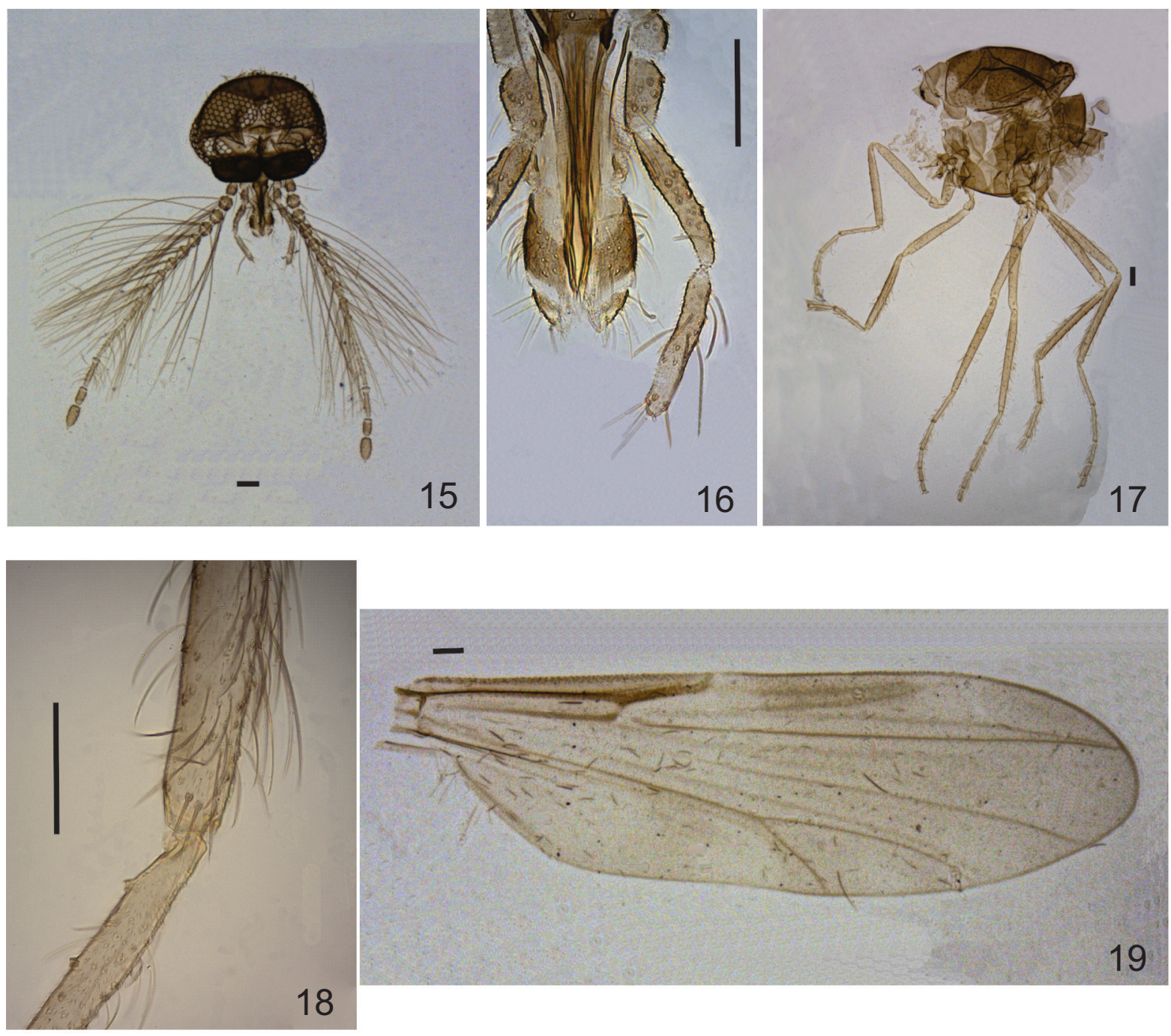

18
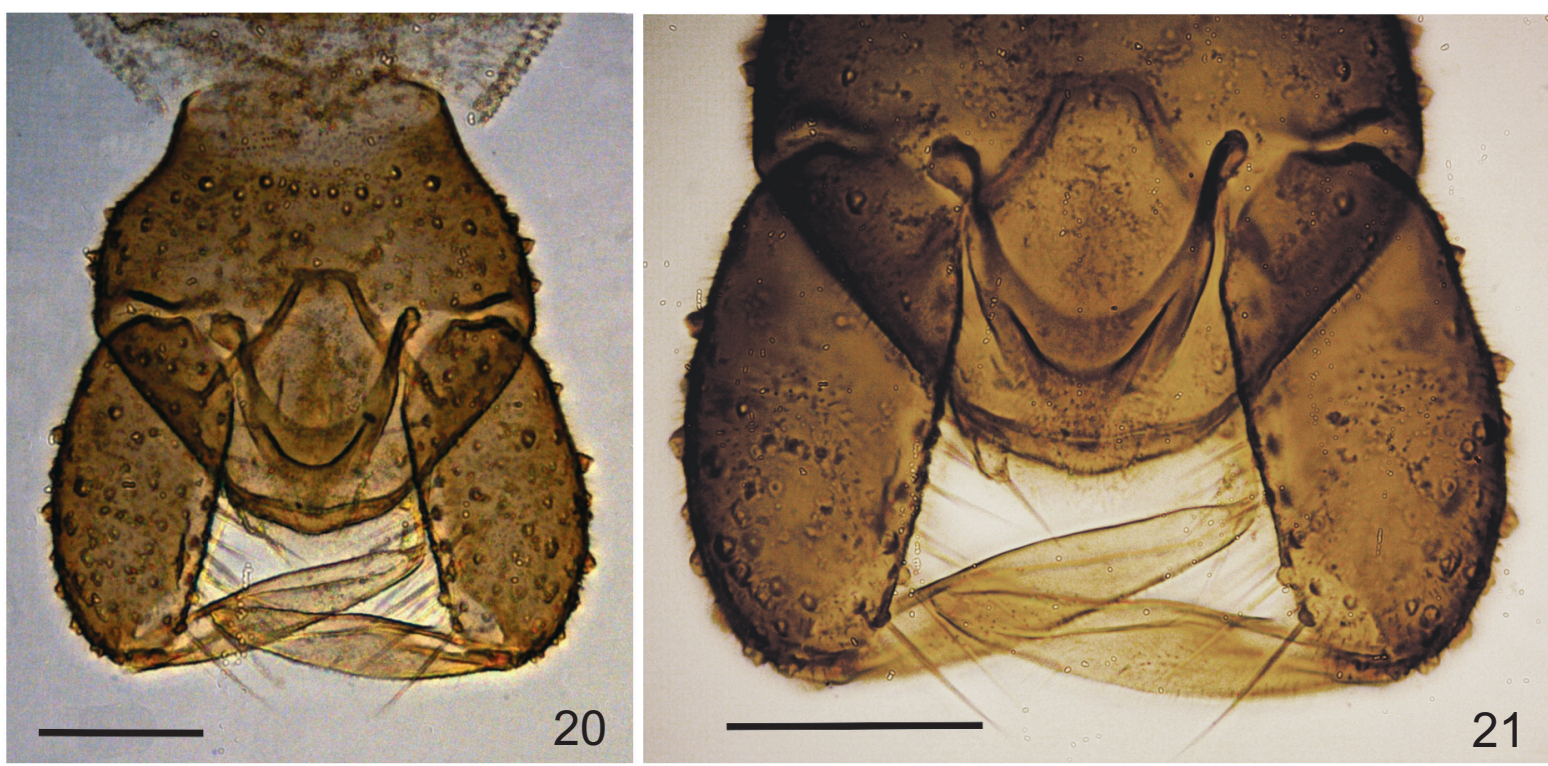

Figures 15-21. Forcipomyia (M.) aidae, male. (15) head; (16) palpus; (17) thorax; (18) hind tibia; (19) wing; (20) genitalia; (21) aedeagus. 

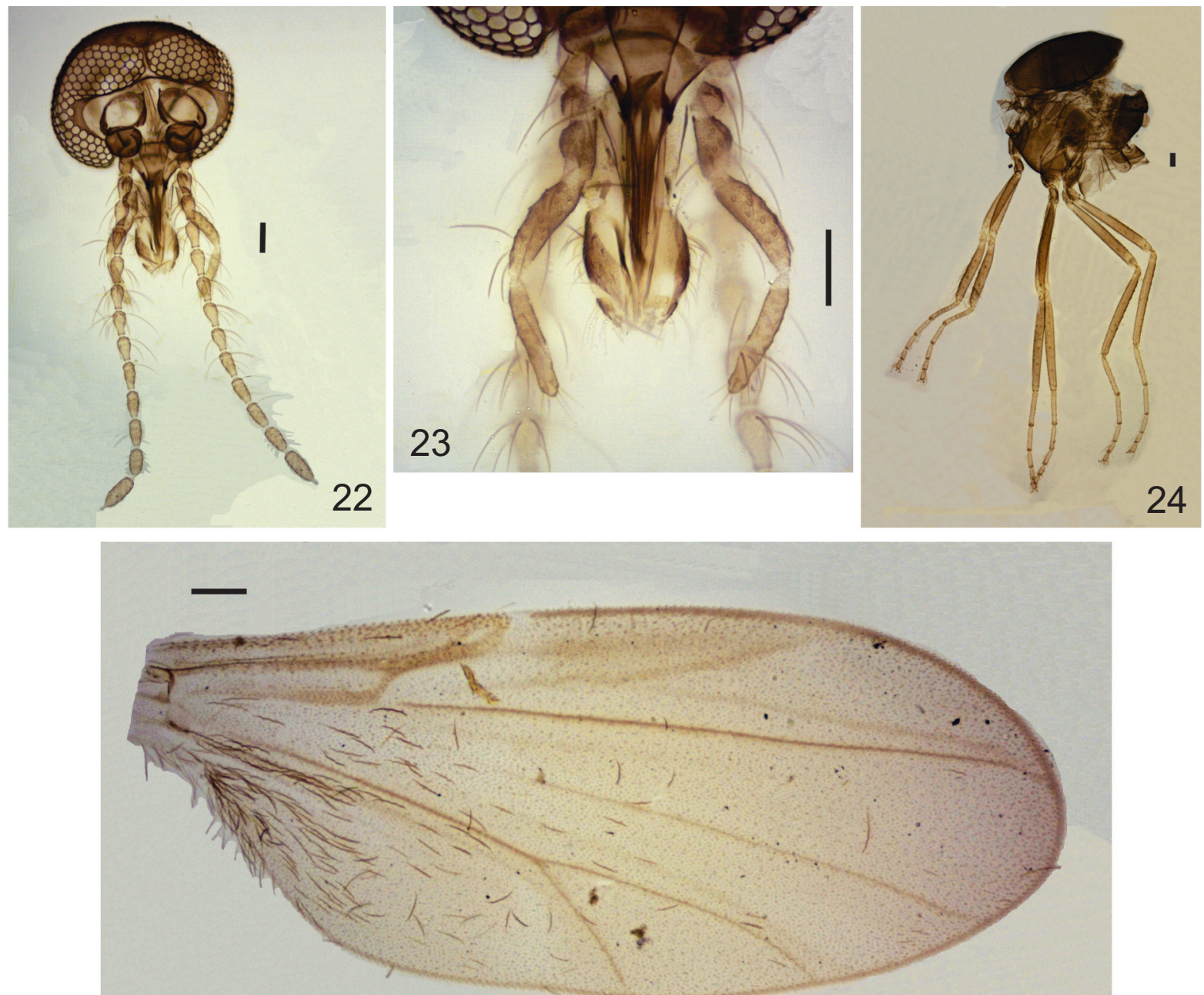

25
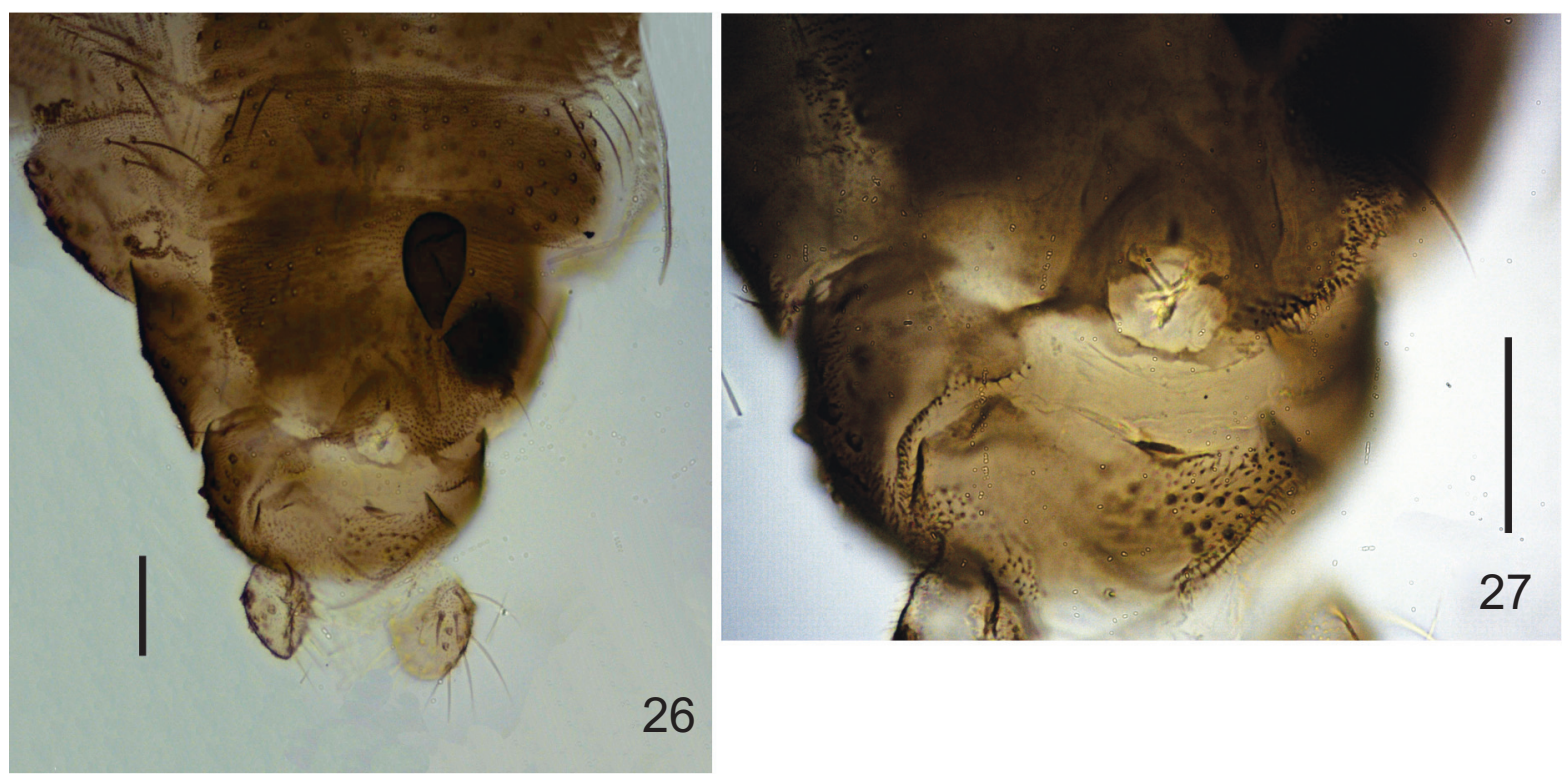

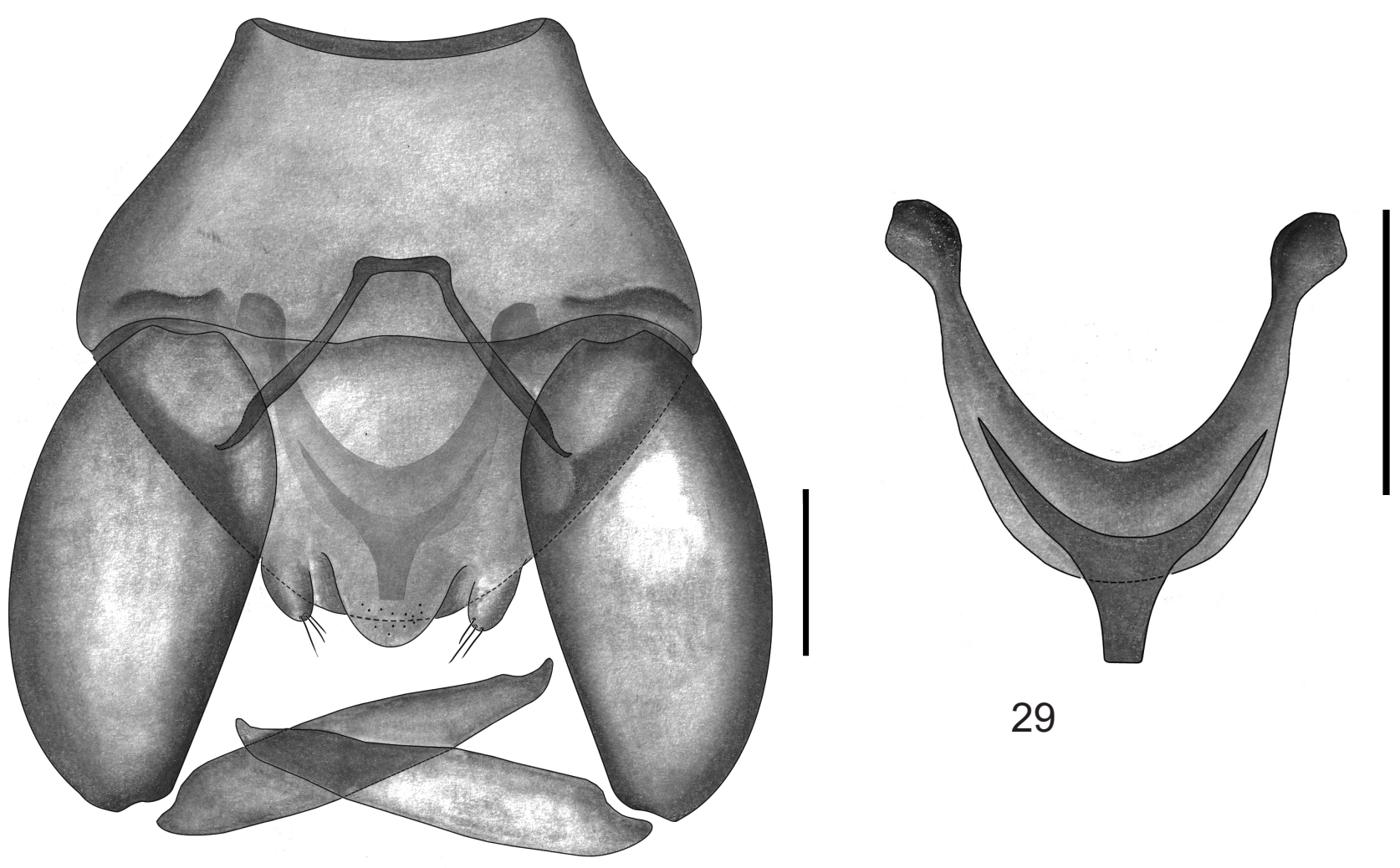

29

28

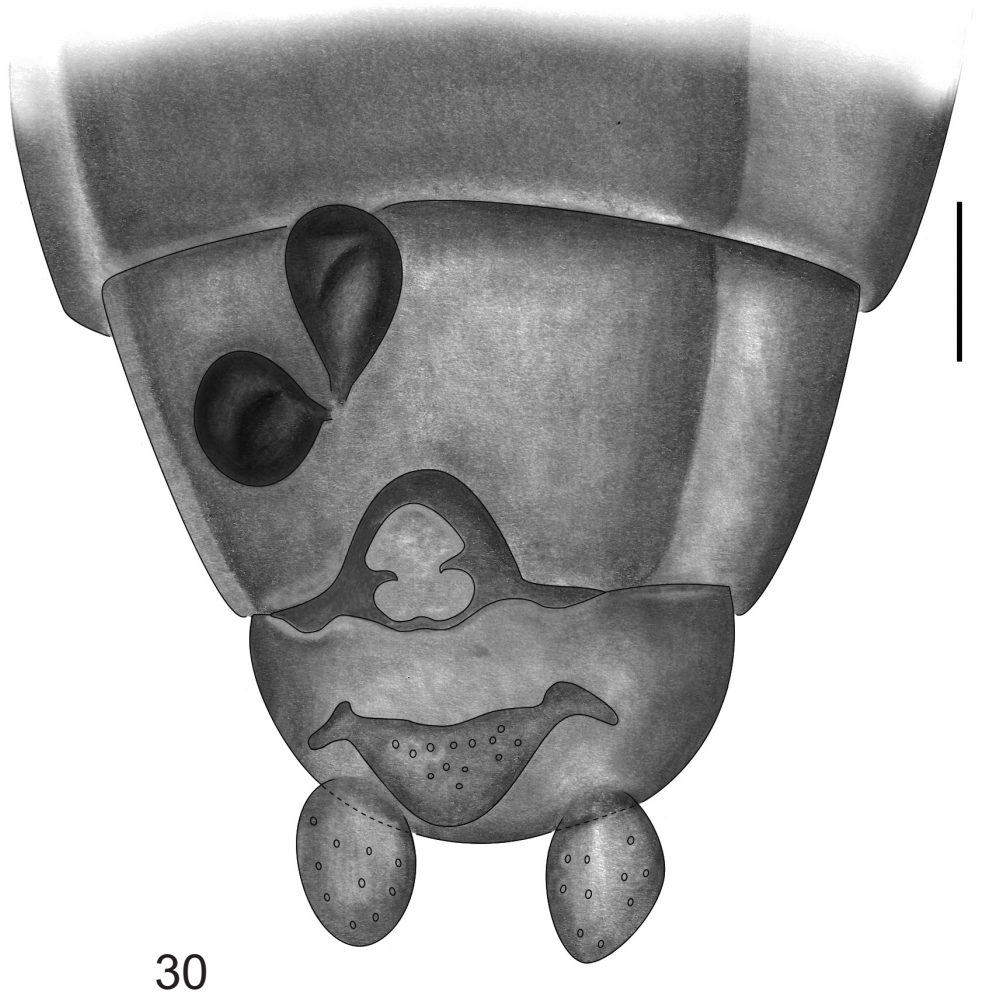

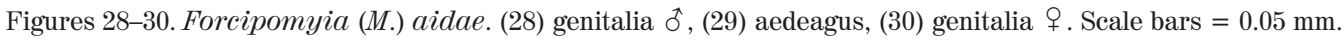

